\title{
HEROES WE LOVE? MONUMENTS TO THE NATIONAL LIBERATION MOVEMENT IN ISTRIA BETWEEN MEMORIES, CARE, AND COLLECTIVE SILENCE
}

KATJA HROBAT VIRLOGET

University of Primorska

Faculty of Humanities

Slovenia, SI-6000 Koper/Capodistria, Titov trg 5

iD orcid.org/0000-0002-6393-7816

NEŽA ČEBRON LIPOVEC

University of Primorska

Faculty of Humanities

Slovenia, SI-6000 Koper/Capodistria, Titov trg 5

iD orcid.org/0000-0002-0998-5614
DOI: $10.17234 /$ SEC.29.2

Original scientific paper

Received: 8. 5. 2017.

Accepted: 10. 10. 2017.

This article is an open access article distributed under the terms and conditions of the CC BYNC-ND 4.0 license.

Monuments to the WW II liberation struggle in the border region between Slovenia and Italy, namely Istria, are the mirrors of conflicting memories at the international and regional level between the two countries and ethnicities, living in the region. As material sites of official memory at the same time, monuments reflect tensions with the individual memories and persistent collective silence decades after the fall of the official memory of the previous Yugoslavian system.

Keywords: monuments, heroes, WW II, northern Istria, conflicting memories, silence, Slovenes, Italians.

\section{INTRODUCTION}

The title of the article derives from the participation in the international project Heroes We Love. Ideology, Identity, and Socialist Art in New Europe (2015-2017), supported by the European program Creative Europe 2014-2020, led by the Maribor Art Gallery. The multidisciplinary project researches the still controversial topic of socialist heritage in the 20th century European art with the focus on socialist monuments within their historical, political and social context.

Some of the findings from our research of public sculpture in Istria, of which the key element is the monument to the National Liberation 
Movement (Narodnoosvobodilna borba), were published elsewhere (Čebron Lipovec and Hrobat Virloget (in print); Čebron Lipovec et al. 2017) whereas some new aspects concerning the conflicting ${ }^{1}$ and silencing memories will be analysed here. A special challenge in this research lies in the complexity of the research area, northern Istria (the part of a region that lies in Slovenia today), a border region which can be defined as a place with troubled pasts deriving from different ideologies, countries, and population transfers. The population of the Istrian towns can be defined as a multicultural society with the officially recognized bilingualism (Slovenian and Italian) (see below).

From the ethnological, but also art history point of view ${ }^{2}$ we will look at two connected topics concerning the conflicting memories linked to those monuments, defined by Riegl (1903) as gewollte, thus intentional monuments, meaning those "sites of memory" that incorporate all those elements of a collective memory that support and highlight the official memory of the hegemonic group and promote its agenda.

\section{POPULATION TRANSFERS AND THE CHANGE OF THE POPULATION STRUCTURE IN ISTRIA AFTER WW II}

Before addressing the problem of memory conflicts in Istria, we have to clarify why Istria is an idiosyncratic example of a contested land and troubled pasts. The region is characterised by being a crossroads, which resulted in a historically transcultural identity, which dates back to the 8th century when the Slavic-speaking (Slovene and Croatian dialects) people of the hinterland used to live together (or side by side) with the Roman-

\footnotetext{
${ }^{1}$ Conflicting memories encompass the memories that are in conflict on and within the different or even the same level: individual ("souvenir") and collective ("mémoire"), related to different social groups, on various scales (local, regional, national or international/global) (see Halbwachs 1992). Selections of these memories can be accepted as official discourse, while the non-selected can be silenced, yet still persist on a non-official level.

${ }^{2}$ The present article is based on the predominant ethnography and art history methodology, but further research should also include history methodology approach, e.g. the use of primary archival sources.
} 
speaking (Istria-Venetian dialect) urban communities in coastal towns. For 500 years this historical contact area had been a part of the Venetian republic of Serenissima, which remains clearly discernible in its Venetian Gothic and Venetian Baroque architecture in urban areas. Afterwards, in the 19th century it was under the Austrian rule that promoted equality among different ethnic groups. However, in the post-WW I and interwar period it became a part of the Italian Kingdom and its Fascist rule under which the Italian nationalism pursued a more than two decades long scorched-earth strategy towards the local Slavic population. Italy's fascist ideology and the process of Italianization of hitherto multi-ethnic areas were the cause for migrations of Slovenians and Croats to the Kingdom of Yugoslavia. In this inter-war period circa 70,000 Slovenians and Croats migrated from the territory of Venezia Giulia (of which Istria represents cca. one third of the area) to Yugoslavia and 35,000 to South America and other countries (still an overlooked area of historiographic research, see Verginella 2015:59-60; Čepič and Nečak 1979). The following period of WW II is intertwined with the Slovenian resistance to fascism, the struggle for ethnic emancipation, and the National Liberation Movement, which are perceived as the foundations of Slovenian identity (see below). Post-war years represent a ground-breaking moment in the history of the region. It was then that the historically intertwined land and society were torn into two parts. The drawing of the border and the related negotiations between Italy and Yugoslavia led, in 1947, to the founding of a temporary buffer-state, the "Free Territory of Trieste (FTT)", which encompassed two Zones: Zone A, which encompassed the area around Trieste and was controlled by the Allies, and Zone B, which covered the northern part of Istria (from Koper/Capodistria to Novigrad) and was controlled by the Yugoslav Army. In 1948, after the exclusion of Yugoslavia from the Cominform group, and its subsequent independent evolution towards self-managed socialism, the area was divided even more. Due to their fundamental incompatibility the coexistence of the two Zones turned out to be unfeasible, so finally, the little temporary state was dissolved in 1954. Hence, Zone B, which encompassed most of the Istrian region, became a part of the Socialist Republic of Slovenia within the Yugoslav federation, while Zone A, which encompassed Trieste with its Karst 
hinterland was integrated into the new Republic of Italy (Pirjevec 2000; Rogoznica 2011).

During the period of FTT and especially from 1954-1955, when the final annexation of this part of Istria to Yugoslavia took place, the vast majority of the original population from the coastal urban centres of Istria left (see Hrobat Virloget et al. 2015). The total registered population of ethnic Italians dropped from $90 \%$ before the war to a mere $7.7 \%$ in Koper/ Capodistria, 8.15\% in Izola/Isola, and 15.7\% in Piran/Pirano in 1957 (Troha 1997:59). According to the data of the Slovenian authorities 27,810 people left the areas of Istria which were under Slovenian jurisdiction between 1945 and 1958 - mostly Italians, but also Slovenians and Croats (Cunja 2004:89; Troha 1997:59) (from a total of between 200,000 and 350,000 migrants from Istria; Ballinger 2003:1, 275, n. 1). The Yugoslav authorities systematically filled the void that remained after the Italians had left by stimulating the inflow of people from inland Slovenia and the rest of Yugoslavia which has completely changed the ethnic, social, and cultural profile of Istria (Gombač 2005:11).

CONFLICTING MEMORIES ON THE INTERNATIONAL AND REGIONAL LEVEL. THE CASE OF ANNUAL COMMEMORATIONS HELD AT THE ANTI-FASCIST MONUMENT IN STRUNJAN/STUGNANO

In the context of the post-war multicultural Istria various types of silenced (individual and collective) memories can be identified. However, the present part of research focuses predominantly on the memories of the Istrian Italians who remained in Istria after the annexation of the region to Yugoslavia (in 1954). In fact, considering the major change of the ethnic structure in the Istrian towns after WW II, as well as Halbwach's (2001) reminder that when people are gone, the memory disappears, these memories represent a very specific, subtle, and precious material/source. Even more so, when we realize that the memories of this group are still being silenced today, within the framework of the Slovenian public discourse.

On the international level, decades after the so-called Istrian exodus, as the migration of mostly Italian speaking Istrians is called in the Italian 
rhetoric, ${ }^{3}$ this is still causing a storm of political and social controversy and, together with the interconnected themes of fascism and foibe, ${ }^{4}$ exodus often becomes a tool in the hands of political discourses (see Hrobat Virloget et al. 2015; Radošević 2011:242; Pirjevec 2009). The Italian and Slovenian sides have defended their parallel histories and multiple reasons for migrations for a long time; they have also come up with different numbers of migrants and differing appellations for them (Verginella 2000; Ballinger 2003:42-45). ${ }^{5}$ Each of the communities demands to be granted the unique status of the victim of historical injustices, and the right to the only historical truth.

Italian migrants see their victimhood as a consequence of the genocide of the "barbaric" Slavs and of the rule of the Communist system, however, the period of fascist violence against the Slavs after 1919 and its victims is "forgotten" (Ballinger 2003:129-167). The local rhetoric of the esuli ${ }^{6}$

\footnotetext{
${ }^{3}$ We use the term exodus in this paper without any political or mythical connotations, without referring to a "monolithic" and "mononational" process as it is understood in the Italian perspective (Ballinger 2003:7). Exodus is the most widely known term, used by all our informants. According to Catherine Gousseff, it can denote almost completely emptying of a population from a territory (oral discussion). The Istrian exodus represents the final stage of Italian migration from Yugoslavia which started shortly after the war, when the Yugoslav National Liberation Army took power in the territories along the Adriatic coast (Istria, Dalmatia), ceded to the Kingdom of Italy after the fall of the AustroHungarian empire (Gombač 2005; Ballinger 2003).

${ }^{4}$ In Italian discourse, the foibe (deep natural sinkholes, common in the Karst region and Istria) have acquired political, almost mythical connotations. They are believed to contain only ethnic Italians who were killed under the alleged Slavic terror (Fikfak 2009a:358; Radošević 2011:243; Dota 2010; Ballinger 2003:98). Slovenian researchers argue that the foibe killings were motivated by ideology as many members of the Slovenian anticommunist home guard and collaborators were murdered there (Pirjevec 2009).

${ }^{5}$ Researchers, however, note that it is highly problematic to number and connect these migrants from a multicultural region after WW II into a single national identity (see XXXX the data was removed by the Editorial in order to preserve the anonymity of the author).

${ }^{6}$ Whereas the migrants and other Italians call the post-war migrants from Istria esuli, in the sense of refugees, exiles (Ballinger 2003), Slovenian historians use the term optanti, which comes from the legal right to opt for Italian citizenship (Paris Peace Treaty, 1947 and London Memorandum, 1954), with the consequent obligation to move to Italy (opting to leave) (Pupo 2015; Gombač 2005:65).
} 
has laid the ground for the official Italian view (especially between 2007 and 2009) that, during WW II, Italy was not the perpetrator but the victim (Fikfak 2009a:358-359, 2009b:374-375). On the other hand, Slovenians and Croats emphasise their victim status under the Italian imperialism and 20 years of fascist violence (Ballinger 2003:129-167, 207-244; Baskar 2010:110-118; Hrobat Virloget 2015a:159-162, 2015b).

Every national memory in Europe is in conflict with the national memory of its neighbour. In the national memories, which are selective, generalizing and instrumentalized, the nations assumed two roles after the WW II: victim and/or resister (Assmann 2007:15, 23). In the confrontation with the negative aspects of its own historical role, when a national memory wants to forget unpleasant events, the following roles are assumed: the winner who has overcome the evil; the resistor who has heroically fought the evil; and the victim who has passively suffered the evil (Assmann 2010:19). Forgetting is an integral part of the process of remembering. The memory unburdens itself of the most tormenting traces of its past and renounces them to construct a positive self-image. For oblivion is not an absence of memory, but a censorship in order to construct a satisfactory self-image (Candau 2005:94). As Aleida Assmann says, “one remembers something in order to be better able to forget something else" (Assmann 2007:15). In other words, a nation recalls its own suffering in order to avoid being reminded of its own guilt. As a result, national memory constructs are not really falsified, but selective as they maintain only a strategic selection of expedient recollections (ibid.:16-17).

Consequently, conflicting memories, concerning the roles of victim/ perpetrator and remembering/forgetting, are transmitted from the national scale to the local spheres. This relation can be clearly seen in the casestudy of the ceremonies linked to the anti-fascist monument in Strunjan/ Strugnano.

The monument was designed as a memorial to the one of the first instances of early Fascist violence in Istria. Namely, on 19th of March 1921 from the windows of a local train a group of Fascists shot at local children playing by the railway, two of whom died immediately, while one remained permanently disabled (Brate 2007). In 1946, this simple vernacular architectonic memorial (Silič Nemec 1982) was erected and 
dedicated to the National Liberation Movement. Due to its simple form, recalling the traditional, historic shape of obelisks, it represents the early post-WW II years. Such monuments are clearly the products of the ordinary people's will to glorify their local "martyrs", who have become heroes, freedom fighters fallen in the liberation struggle (Čebron Lipovec and Hrobat Virloget (in print); Čebron Lipovec et al. 2017; Purger 2016; Čopič 2000; Klabjan 2012; Silič Nemec 1982). Iconographically, the monument from Strunjan/Strugnano shows the double ethnic appurtenance of the area and of the freedom struggle, with two different caps: one of the Slovenian partisan with the cap triglavka, recalling the shape of the mount Triglav - a national symbol, the other of the Italian garibaldini (Fig. 1).

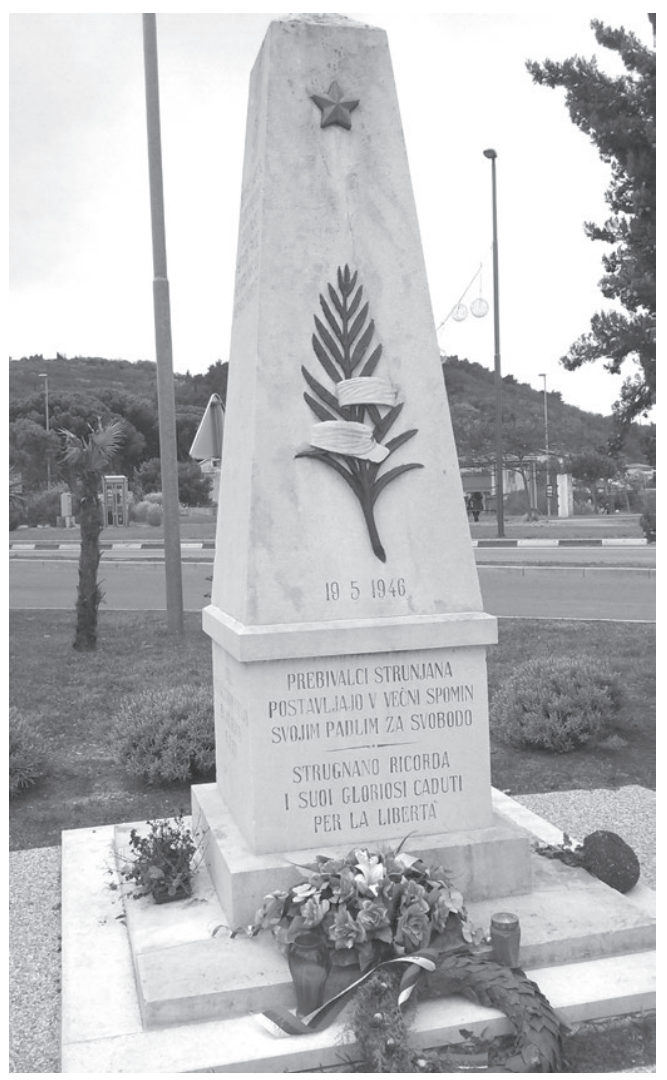

Figure 1: Monument to the Liberation Struggle and the assassinated children in 1921, in Strunjan/Strugnano, anonymous author, erected in 1946. (Photo: Katja Hrobat Virloget) 
In the Istrian environment, the monument assumed the role of lieu de mémoire of the cornerstones of Slovenian and especially regional (Primorska) identity: the victimisation and the heroic resistance under the Fascistic oppression, the struggle for ethnic emancipation during WW II, and the National Liberation Movement (Fikfak 2009a:359; Hrobat Virloget 2015a:161). The meaning of this monument on the national level can be discerned also from the highly popular and important speakers who were invited to give official speeches at the commemorations. In fact, on the commemoration on 20th March 2015, the official speech was given by Peter Bossman, the mayor of Piran/Pirano, and the President of the National Assembly dr. Milan Brglez. The abovementioned values were stressed by both of them. The mayor (it is relevant to note that he is originally from Ghana, Africa) held a typical speech for the usual commemorations of the anti-fascist struggle during WW II (for example Hrobat Virloget 2015a:161):

“... on fascism as evil/ And we are proud, that the Slovenian nation has made an important contribution to the victory of the Allies. /.../ We have shown that Slovenes will never be helpless victims, but will always fight back vigorously. /.../ A nation that fights so bravely for its survival and for its dignity can neither be stripped off its homeland, nor of its future. Thank you."'

The excerpt from the mayor's speech stresses the victimhood and heroism of Slovenian nation within the framework of a typical nationalist discourse, while the Istrian Italians are not mentioned at all. As Stuart Hall argues, nations construct their identities by selectively binding their chosen and memorable achievements into a "national story" which is reflected in the national heritage. The ones that cannot properly see themselves in this mirror cannot properly 'belong' (Hall 2008:220-21). This seems to be the case of the Italians that remained in Istria, who find it difficult or even impossible to identify with these kinds of nationalistic discourses of the region.

\footnotetext{
${ }^{7}$ We are thankful to our collegue Andrej Preložnik for recording the commemoration on 20th of March 2015.
} 
Despite the links between the Slovene and Italian freedom fighters in the antifascist war, this element of brotherhood has very rarely outweighed the national agenda of the new Slovenian authorities in the area (see also Rogoznica 2011:298-304). The interviews with Italians from the region reflect their disappointment at being so easily ignored and equalised with the Fascists. According to the words of a local member of the Italian community, a former president of the Italian elementary school, the Italian minority was too often neglected and/or hurt every time they took part in the commemorations at Strunjan/Strugnano with their pupils, so finally they refused to participate: ${ }^{8}$

"But those were Italians who killed Italians. Those children who were killed in Strugnano were Italians. /.../ But at these manifestations sometimes, especially on the part of the older speakers, it comes out differently somehow... They do not speak against Italians, (but) against Fascists, ...yet we are there, present, our schools... It has not always been, well, pleasant to be there at this manifestation.../... But we said enough, enough of this now, always the same stories, year after year and we have always been polite... But now - enough!"

In the predominant collective memory the Italian population was collectively held responsible for the war crimes as well as for the previous three decades of violent Fascist politics of ethnic cleansing and the imposition of the Italian culture as superior (Hrobat Virloget et al. 2016). Italian families holding antifascist and socialist beliefs were already bitterly disappointed with socialist Yugoslavia and its promises of brotherhood and equality among the ethnic groups, when they experienced Yugoslav nationalism coupled with collective criminalisation (Ballinger 2003:129-167, 207-244; Nemec 2015; Hrobat Virloget 2015a). By focusing the national memory on the concept of victim and the guilt of the other nation, a protective shield from the memories of "the other" was made. In this way, it was practically impossible to acknowledge the status of the victim of "the other" and to deal with one's own guilt and accountability (Assmann 2007:17).

\footnotetext{
${ }^{8}$ Due to the sensitive topic of conflicting and silenced memories, we prefer not to expose the identities of interviewees. All the interview transcripts are kept by the authors of the article.
} 
Although it too focused on the victims of fascism and the heroic resistance as the cornerstone of Slovenian identity, the speech by dr. Milan Brglez was slightly different in that it highlighted the importance of mutual understanding between Istrians, Slovenes, Italians, and Croats:

"/On the fascist killing of children/. This action was just another nail in the coffin of intercultural coexistence in this area. Unfortunately, this event marked only the beginning of the persecution of all the people from the area, who spoke Slovenian. Italianizing names and surnames, banning the Slovenian language and prayer in churches, and in the conversations in the streets, all of this was prohibited in the days, weeks and months that followed. /.../ Many have suffered, many also gave their lives because they were speaking their mother tongue. /.../ Despite black thunder clouds, the Slovenian language and culture survived /.../. Without them /Istrian heroes/, Slovenian language would not be spoken in this area today. Moreover, this would not have been possible without the brave men and women, whether they be of Slovenian, Italian or Croatian national provenance, which liberated this territory from the Fascist oppression."

The speech of dr. Milan Brglez continues with a national selfreflection about the dark sides of our "just" liberation fight, as he describes the National Liberation Movement (see citation in Hrobat Virloget 2015a:161-162), which resulted in the drastic change of the demographic structure of the post-war Istrian society, empty towns, changed toponyms etc. Indirectly the speech seems to allude to the exodus and its consequences and this is a rare case of a political speech evoking the events that were predominantly silenced in the Slovenian collective memory. With its stress on the multicultural co-existence and common anti-fascist struggle this speech fundamentally differs from other commemoration speeches in the area. By interweaving the two conflicting memories, i.e. those of the Slovenians and the Italians, both of which focused on victimization (for Slovenians it is being under fascist rule, for Italians exodus), the speech of a politician experienced in international relations leads to what Aleida Assmann calls an ideal of a European shared memory. It occurs only when the national memories have succeeded in establishing the victim as well as perpetrator consciousness by confronting with its own memories and listening to the others with empathy (Assmann 2007:22-23). 
Significant steps towards reconciliation between the conflicting Slovenian and Italian national memories have also been made on the international level by acknowledging the victimhood of "the other". Crucial was the year 2010, when the Presidents of Slovenia, Croatia and Italy came together to lay a wreath at the national lieux de mémoire in memory of the victims of Fascism and in memory of the optanti or esuli (Hrobat Virloget 2015a:160-161). ${ }^{9}$

Nevertheless, despite there having been attempts at constructing a shared memory on the international level, and even their penetrating the local Istrian reality, the predominant regional memory of the Slovenian Istrians remains caught in its victimhood as the cornerstone of the Slovenian and regional identity, which does not allow for listening to the memories of "others", those that are living side by side. Although they consider themselves a multicultural society, the presented case indicates a reality that is quite different, at least in relation to the collective memories concerning the post-war period; more than an empathic multicultural community with a shared memory, Istria figures as a society of "strangers either way" (Čapo Žmegač 2007).

\section{MONUMENTS AND HEROES OF THE NATIONAL LIBERATION STRUGGLE. BETWEEN CARING FOR THEM AND SILENCING}

Memories which are found inappropriate for the collective self-image and therefore excluded from the national discourse (Assmann 2007:16) are not only the memories of the "other", but also the memories among "us".

Among the monuments dedicated to the National Liberation Movement in Istria, two types of attitudes of the general public can be discerned. After the fall of the "Iron Curtain" and the 1991 independence of Slovenia, the period of socialism in Yugoslavia and the National Liberation

\footnotetext{
${ }^{9}$ Even today conflicting national memories prevail, which can be discerned in the annual marking of the days of rememberance on the Italian and Slovenian side. The Italians commemorate the victims of the exodus and fojbe, while the Slovenians celebrate the victory, i. e. the anexation of this region to Yugoslavia (see Hrobat Virloget 2015a:160-161).
} 
Movement gradually underwent a process of censorship and revisionism in view of the ascending capitalism and its links to the politics of memory. As Kristen Ghodsee (2014:134-137) has shown, the double genocide narrative, equating Holocaust victims with the ones of communism, has appeared right at the time when neoliberal capitalism was facing devastated economies and inequalities of wealth. The production of the European idea of "communist victims" indicates an intellectual paradigm which prevents a return to the leftist politics thereby precluding any possible move towards redistribution and free market.

After the independence in Slovenia in 1991, the change in the sociopolitical system from socialism to capitalism was by far not as drastic as in other Eastern European countries since the National Liberation Movement and the socialist past were considered a milestone leading to the Slovenian emancipation and national independence, for which they had waited for centuries. This process encompassed a parallel process of nationalisation of the Yugoslav Partisan Movement which in the Slovenian official discourse, especially after the Slovenian Independence, was represented namely from the Slovenian national perspective.

Nevertheless, conservative forces and neoliberal orientations have gradually diminished this positive perception, especially of the socialist experience, and in the name of liberalisation irreversibly changed and censored its material reminders (Hrobat Virloget et al. 2016). One glaring example of this, are the recent demolitions of schools in Koper/Capodistria (between 2005 and 2008), which were important examples of Modernist architecture (Čebron Lipovec 2012). The buildings as the potential longterm holders of heritage meanings are removed, and with them the memory of the period in which they were built. Thus the memory of the "heroes", who co-created this past and to whom these schools were dedicated, dissolved together with them (Čebron Lipovec et al. 2017). The buildings were replaced by generic low-quality new constructions or worse remained forever unfinished building sites. These cases are indicative in terms of our current relation to the art and architecture during socialism as well as to our own socialist past. Demolitions are not the result of oblivion, but rather the censorship of memory (Veschambre 2008; Halbwachs 1992).

After the destruction of these architectural lieux de mémoire the 
local authorities collected the bronze busts of national heroes which were originally made in connection with the building of the aforementioned schools. The schools bore the names of the partisan heroes Janko Premrl Vojko, Pinko (Pino) Tomažič and Anton Ukmar - Miro. ${ }^{10}$ These three busts were placed together in a public park (Hlavaty Park) at the edge of the historic centre of Koper/Capodistria. Later, another three busts, recently produced, were added, i. e. those of Albert Klun ${ }^{11}$ and of Kazimir Renčelj, ${ }^{12}$ followed by a recently added sixth bust of a partisan hero (placed between those of the two young heroes) - featuring Karlo Maslo. ${ }^{13}$ His bust, made

${ }^{10}$ Janko Premrl - Vojko (1920-1943), originally from the Northern Primorska region, was a "legendary partisan hero and symbol of the freedom fight" (Žigon 2013) in his lifetime. As a squad commander he died fighting the fascists in the Trnovski gozd forest at the age of 23. The school named after him was built in 1948-1951, thus the first postwar construction to be erected after WW II in the historic town of Koper/Capodistria, and intended for pupils of both ethnic groups (Čebron Lipovec 2012). It was demolished in 2008 following physical planning changes aiming at gentrification; the site of the school was to be converted into a luxury apartment complex which was never even begun. Pinko (Pino) Tomažič (1915-1941), a Slovenian from Trieste, was a prominent Communist leader, activist and revolutionary, who was condemned and shot after the Second Trial of Trieste (December 1941) at the age of 26 (Kacin-Wohinz 1990). The school named after Pinko Tomažič was the second elementary school of Koper/Capodistria, built in 1962, and an outstanding example of modernist architecture; it was torn down in 2005, to be replaced by a new, larger, prefabricated building. The third bust is that of Anton Ukmar - Miro (1900-1978), originally from Prosek/Prosecco in the hinterland of Trieste, a prominent figure in the international brigades during the Spanish Civil War, later a "liberator of Genoa", and a major figure in the Slovenian Communist Party in Trieste and in Koper/ Capodistria during and after the Free Territory of Trieste. He was declared a national hero in 1981 when his bust was placed at "Ukmarjev trg" (Ukmar's Square) t the historic centre of Koper/Capodistria, and the school (still standing) is at the suburb quarter of Koper Markovec. The historic building, serving as the background to the bust in the historic centre, was knocked down in 2006, in line with the urban renewal plan, and replaced by a large lawn as public space.

${ }^{11}$ The bust was made in 2006, probably by Zmago Posega. He was a partisan and a historiographer of the Overseas Brigade.

${ }^{12}$ The bust was made in 2006, by Zmago Posega. He was a Naval Commander in the Maritime Coastal Sector of Trieste.

${ }^{13}$ A member of the national liberation struggle in the Karst and Coastal region, Commander of the Istrian division, who was declared a national hero in 1953 (1912-1988) (Plahuta 1984:385-386). 
in 1981, was placed in the park in 2010. All these busts are "assembled" as if they were dumped in the back row of the local Hlavaty park, forming a line under the shrubbery as if to create a barrier with the park and its contemporary forma-viva sculptures, a fountain, and children's playground in the back, and a gift shop in the front. The whole area looks like a "clipboard" or a "parking lot" of monuments (Fig. 2), whereby memories are meshed together and left aside and easily fall into oblivion.

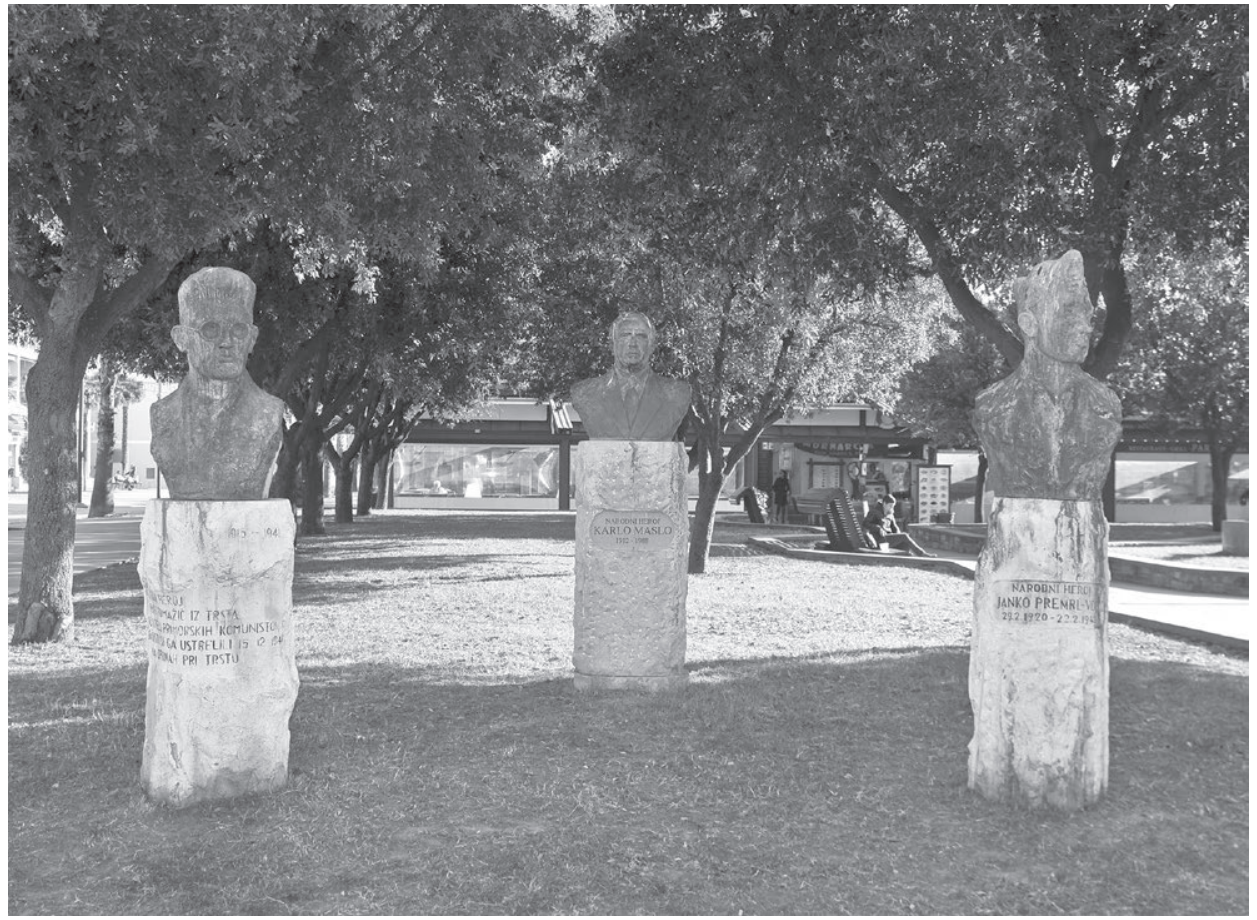

Figure 2: Assembled busts of WW II heroes in Hlavaty park, Koper; northern part, lefthand side - Pinko Tomažič (author Jože Pohlen, 1968), centre - Karlo Maslo (author Vlasta Zornko, 1981), right-hand side - Janko Premrl - Vojko (author Jože Pohlen, 1968). (Photo: Zdenko Bombek)

It is only on 1st November that these artworks and their historical context are brought to life during the commemoration ceremonies, held by the Association of Slovenian Freedom Fighters (Zveza združenj borcev za vrednote NOB), in which the larger community barely participates. It is relevant to point out that the six assembled busts refer to personalities 
important for the Slovenian nationality. As such even today, in the independent Slovenia, they play the role of the national symbols, despite their role in the "socialist past". Therefore, this "memorial park" is a textbook example of preserving the past official (Yugoslav) memory, which was nationalised within the Slovene national identity "lens". Although it is no longer dominant, its message of the anti-Fascist fight still forms the basis of the contemporary Slovenian identity.

However, we also need to stress that participative care for monuments dedicated to the National Liberation Movement is much more present in the rural areas than in the cities (Čebron Lipovec et al. 2017; Purger 2016). In the villages, the monuments are thoughtfully cared for and maintained, mostly by the local communities, with the help of local schools which help in the cleaning and brushing of the monuments every year. Financial support comes from the municipalities and from the Association of Slovenian Freedom Fighters. However, we may assume that these monuments do convey meaning to the local inhabitants and represent an anchor to their collective past and identity (there are usually family members from the villages among the victims).

In the urban context such collective attachments are not revealed, either to the reminders, or to the history they personify. What is even more striking - as we shall see shortly - it seems that it is the collective ignorance on the part of the city residents that makes it possible for the bust of an "antihero" of sorts to be placed among the heroes.

Whereas the mentioned displaced busts, which were the "leftovers" of the demolished buildings, were made at the time of the construction of the buildings (1950s, 1960s, 1980s), the three of the six busts in the park were placed there quite recently, between 2002 and 2008. The three personalities belonged to the same Socialist or National Liberation Movement period and were prominent actors in the Slovenian nation-building process during socialism. Hence, the obvious question to ask is: who placed these monuments there and why? Interviews and questionnaires, carried out by the local high-school students among the local residents, showed that the current residents know almost nothing about these personalities, especially when it comes to the three new busts.

Furthermore, research of individual memories showed that one of them was placed in this "clipboard of monuments" because the local people 
refused to place his bust in the area where he originated from. It is the case of Karlo Maslo, who is represented in the official memory as a national hero (since 1953), but turns out to be a controversial figure in the local collective and individual memory. When the idea of erecting a monument to Karlo Maslo was proposed, the municipality of the region of his provenience (not Istria, but neighbouring region of Brkini) - Kozina-Hrpelje, after much debate, refused to place the monument in their area. ${ }^{14}$ Let us just note that the monument was also not placed in the municipality of his origin, Ilirska Bistrica. ${ }^{15}$ In researching the background of this figure we encountered an impressive amount of collective silence. When we tried to get some data about him through friends from the area, we received answers such as: "I hope you haven't told them that somebody from /...the village / knows about him!!!", or: "You are walking on thin ice." Only horrific fragments were documented, like: "the one who was killing people (after the war) with a pick", "many people lost their life because of him for nothing", "women would never let him get out of his village alive if he were brought in", "a rapist" etc. ${ }^{16}$ Analogous accounts of multiple rapes and other similar misdeeds are recorded and retrievable through personal on-line blogs, ${ }^{17}$ and even in a published monograph (Perme et al. 2000). At the time of the writing of this article the memories of this anti-hero, personalizing the perversion of politics after WW II (at least in this region), are still not fully researched because of the collective silence about it. ${ }^{18}$ As somebody commented: "it was worse after WW II, than during it".

The very recent placing of the bust on a tall plinth in a public space of a hero who is mostly unknown to the community where his bust stands

\footnotetext{
${ }^{14}$ Besides oral sources newspaper articles informed about the postponing of the erection of the monument. http://www.primorski.it/stories/alpejadran/49739_heroj_aka_na_ spomenik/\#.WZRSK9R97Gg.

${ }^{15}$ There is however a statue of his mother, since all of her children were partisans, erected in front of a kindergarden that was named after her, but also this lieu de mémoire is a matter of dispute (see http://www.primorske.si/Primorska/Srednja-Primorska/Borci-drugic-vboj-za-ime-bistriskega-vrtca.aspx, accessed August 18, 2017).

${ }^{16}$ Informants want to remain anonymous.

${ }^{17}$ Tatjana Malec writes http://www.pozitivke.net/article.php/OCrnihBratih

${ }^{18}$ Even if the family of one of the authors comes from this region.
} 
and whose reputation of an anti-hero is upheld by the people of his region of origin (Brkini) - points to the fact that there is a clear dissonance, even antagonism, between the official and individual or collective memories in the practice of erecting monuments.

The proposal for erecting the monument seems to have come from the National and Association of Freedom Fighters and its local units which together with host municipalities, of which the last in a row was Koper/ Capodistria, organized the ceremony to mark the occasion on 24th April 2010. Speeches of different representatives of this political sphere indicate how the official memory discourse selected only those episodes from Maslo's biography and actions that were compatible with the national discourse of the National Liberation Movement. An intellectual and a former politician Janez Stanovnik, the leading senior figure in the National Association of Freedom Fighters, stressed the "triptych" of three national heroes (Janko Premrl - Vojko, Pinko Tomažič, Karlo Maslo) had a "symbolic meaning, foremost for their deeds in the anti-Fascist fight" and that they "personify and symbolize the struggle of the Slovenian people for freedom". ${ }^{19}$ Maslo's comrade in arms Dušan Puh confirmed his heroism, saying:

"He was a hero in the truest sense of the word. /.../ He triggered the explosion of rebellion /.../ which had been accumulating due to hatred and longing for freedom during the decades of the Italian genocide violence over the people of Primorska." ${ }^{20}$

Within the current political scene, the figure of Karlo Maslo was also actualised as a model for younger generations, as the mayor of Koper/ Capodistria Boris Popovič, states:

"Maslo's brave path and his faith in the just cause can, without a doubt, be a model for younger generations today. /.../ Karlo Maslo represents the harmony and unity of the nation that our ancestors put in our cradle." ${ }^{21}$

\footnotetext{
${ }^{19}$ https://www.youtube.com/watch?v=rDO_XxSTkzY (accessed August 16, 2017).

${ }^{20} \mathrm{https}$ ://www.youtube.com/watch? $\mathrm{v}=\mathrm{XZXmNpimyYo} \mathrm{(accessed} \mathrm{August} \mathrm{16,} \mathrm{2017).}$

${ }^{21} \mathrm{https}$ ://www.youtube.com/watch?v=XZXmNpimyYo (accessed August 16, 2017).
} 
Karlo Maslo was thus re-actualised as a national hero in the official speeches which intentionally ignored all the difficulties that accompany putting of his bust up almost thirty years after it was made.

From the ethnological point of view it is not so much the historic truth about this anti-hero that is interesting, but the persistent collective silence. The situation can be compared to the one in Croatia, where after WW II only one official memory existed, the one of anti-Fascist fighters, which became sacred. A non-official memory was still preserved at the margins, especially in the diaspora. The end of socialism and the democratic processes of the 1990s re-examined the winners, i.e. the anti-fascist fighters, who were until then protected from any criticism. Furthermore, it led to historic revisionism, to the criminalization and demonization of the winners and the rehabilitation of the defeated Ustasha (Čapo Žmegač 2015:123-124; Cipek 2009). Generally, the collapse of the bipolar political system in 1989 triggered the explosion of suppressed memories all over Europe. Many of the former nations from the Eastern bloc are still in the processes of re-elaborating the national myths and creating new ones today, based on the intertwined memories of both persecutions and collaborations; both victimization and guilt (Assmann 2007:16). Yet, in the given case study it is outstanding that the suppressed memories (about some heroes or post-war times) of the ordinary people did not "explode" - as could be expected after the fall of the system which was prescribing the official memory - but still kept the collective silence.

Why this collective silence? Is it because the Slovenian identity is still based on the "just" Nation Liberation Movement struggle and any tarnishing of it is still considered inappropriate? It reminds us of Orlando Figes's book The Whisperers (Figes 2007) which talks about the ordinary people under the Stalinist system having to whisper from fear of being heard. People got used to living double lives: information, thoughts, religious belief, family values, interpersonal relationships, and everything that was not congruent with the measures of the Soviet existence was hidden from one's neighbours, even from one's own children. People learned to whisper (Figes 2009:13). Similarly, people from Brkini "had to be careful of what they say /.../ because they ended up in jail for every incorrect word." 22

${ }^{22}$ Anonymous interviewee. 
Why still whisper today? Apart from psychologic reasons, which should be studied by experts, the reason can be found in the incompatibility between the individual or collective memories of the whole villages or regions and the official national memory. This also reminds us of the silence of pied-noirs, in the context of the Franco-Algerian war. When speaking about it, Andrea Smith (2006:147-159) noticed that people were self-censoring, silencing and disciplining of the memories, actively trying to avoid them, or structuring them in a rational, non-personal way. People resorted to these tactics in order to have the control over their emotionally charged memories, which were incompatible with the French national memory about the war and which, at the same time, also reminded them of their personal involvement in the unspeakable and shameful atrocities in what was very close to a civil war, and had only recently been acknowledged by the national memory. A similar silence was found among the Italians who remained in Istria after the so called exodus as a minority (Hrobat Virloget 2015a:172-175, 2017).

Questions raised during the course of the memory analysis can be indirectly identified through the formal art history analysis of the sculptures. As we could see, the formal treatment of Maslo's sculpture very clearly shows that it was made in a different context, for a different purpose, and dedicated to a person who greatly differs from the two other heroes represented by the neighbouring busts in the park. The bronze bust of Karlo Maslo is standing today between the busts of two other national, wellknown heroes - Pinko Tomažič and Janko Premrl Vojko, both created by the most prominent local sculptor of the post-war period, Jože Pohlen (Čebron Lipovec 2017; Božeglav 1986). Maslo's bust was made in $1981^{23}$ by the artist Vlasta (Vladimira) Zorko Tihec, ${ }^{24}$ without a precise location to be displayed in (Zorko 2016); as a result, it visibly differs from the other two.

\footnotetext{
${ }^{23}$ The background to the construction of the sculpture was described by the author Vlasta Zorko, during the interview on 13 May 2016. We are grateful to XXXX the data was removed by the Editorial in order to preserve the anonymity of the author who organized and carried out the interview with the artist. It is a unique source of information regarding the subject.

${ }^{24}$ Vlasta (Vladimira) Zorko (1934) is an active Slovenian sculptor, living and working in Maribor (see Znidarčič and Ilich-Klančnik 2013).
} 
We need to bear in mind that the current location of the other two busts is only secondary: originally, Pohlen's busts were placed in front of the two schools named after the two heroes. Pohlen's sculptures show several formal analogies. On the left hand side of Maslo's bust in the front, the bust of the hero of the National Liberation Movement, Janko Premrl Vojko (made 1968) - shows a young partisan with triglavka, the typical cap worn by Slovene partisans, which recalls the shape of the highest mountain and the national symbol - the mount Triglav. It features a very neat surface with tense facial muscles, depicting the hero's young age of 23 at the time of his heroic death, yet his piercing gaze is directed towards the open horizon, metaphorically towards the future, and the head is dynamically turned to the left, stressing the romantic optimism of the whole work. The structuring of the other hero is similar. The bust depicts a communist intellectual and activist from Trieste, Pinko Tomažič (made in 1968) and is placed on the right hand side of Maslo. Tomažič's bust is also facing right, but gives a different impression: the expressively chiselled cheeks, especially the eyes that are dug out so to shape two cylindrical holes, are accentuated by the frame of his glasses. The focus on the eyes that "see deeper" is interlaced with the messy hair and tense lips, in order to portray a vigorous intellectual. We should bear in mind that both sculptures were clearly made posthumously, based on visual documents. Both busts rest on roughly carved stone pedestals with a smooth front which bears the inscription, also made by Pohlen. The rugged stones complement the expressiveness of the bronze statues. At the same time, they reflect Pohlen's individual stamp on the monumental stone sculptures that recall the texture of the earth (Božeglav 1986).

Compared with the two "neighbours" in the park, the bust of Maslo is treated visibly differently: Maslo is presented in his later years (while the two other heroes, having died very young, cannot be presented otherwise than at their young age). Furthermore, it is characterised by meticulous naturalism. The figure is set frontally - as if the portrayed was standing ceremonially, the surface of the bronze is smooth, giving an altogether cold, serious, unapproachable impression. Last but not least, the stone pedestal, which was made separately from the bust itself, is treated in a different, more industrial manner. The realistic approach to the figure design seems to indicate a discernible and intentional lack of personal interpretation in its sculpting. As we learnt from the author herself, she sculpted the bust after having met 
Karlo Maslo in person when the work was commissioned by the Association of Slovenian Freedom Fighters. ${ }^{25}$ According to the words of the sculptor Zorko, at the time of Tito's death, it was permitted to display the bronze sculptures of persons still living, in public spaces. ${ }^{26}$ As already mentioned, the bust did not have a dedicated display site, which surely contributed to the fact that it was not placed anywhere for almost thirty years.

\section{CONCLUSION: MONUMENTS AS SITES OF DIVISIVE MEMORIES AND SILENCES}

The two case studies of memorials from Istria reflect the definition of memory by Luisa Passerini (2008:224-225) as "the relation between present and past, silence and word, between individual and collective /.../." Monuments contribute to official memorial codification and they express the decision according to which representations of the past will be shown publically and eventually shared (Candau 2005:125). With the creation of public space of memory "the monuments propagate the illusion of a shared memory" (Young 1993:736; after Candau 2005:125). Máté Zombory mentions the obsession of totalitarian regimes with exploiting monuments for political ends and expresses the interesting notion of "the monument as a piece of stone with fixed meanings, in itself establishes a link with the past that brooks no contradiction" (Zombory 2012:51). In the concept of Pierre Nora's lieux de mémoire, history and memory intersect and coalesce into the present. "But if we were able to live within memory, we would not have needed to consecrate lieux de mémoire in its name" (Nora 1989:8; Zombory 2012:60-61).

In the presented case studies from Istria, monuments do brook contradiction. In contrast to the monuments dedicated to the National

\footnotetext{
${ }^{25}$ From the interview with the artist, we learn that in 1980 the Society of free-lance artists, mainly sculptors, was contacted by the Association of Slovenian Freedom Fighters who sent a list of important personalities who had to be portrayed. Vlasta Zorko was commissioned at the same time four portraits: Vida Tomšič, Albina Hočevar, Franc Poglajen and Karlo Maslo (Zorko 2016).

${ }^{26}$ This information was provided by the artist Vlasta Zorko during the interview, who explained that at the time of the execution of the bust it was still not allowed to place in public scultpure of still living persons, yet the list of personalities to be portrayed was made somehow "on stock" so to be ready (Zorko 2016).
} 
Liberation Movement in the countryside, which are cared for because of the memory that seems to be alive in the village communities, the basis for the regional and national identity (still prevailing) are the values of the fight against fascism that serve as an anchor to their collective past and identity (there are usually family members from the villages among the victims), other monuments seem to present anything but a shared memory.

Due to commemorations a monument can embody divisive memories even though the original aim, expressed through iconography, was to be a reminder of the two ethnic groups' shared memory, i.e. the Slovenes and the Italians. Despite the attempts to listen to "the other" with empathy, on the international and regional levels, the memory has remained stuck in the nationalist discourse rendering its protective shield from "the other" (Assmann 2007:17), although they live side by side.

The second case study shows the discrepancy in the image of a national hero: it is only in the milieu where he was not known, that he could assume values of a hero, while among the members of his home community he represents the opposite, an anti-hero. The collective silence about him and the events following WW II is shocking. It has persisted for more than three decades after the fall of the system which was prescribing the official memory. Besides ascribing the persisting collective silence to the incompatibility between the individual and regional memories and the national collective memory, there are also deeper reasons, connected with psychological aspects, due to which "silence became the base, constructor of peoples' identity". ${ }^{27}$ This fragment about the psychological aspects of silence opens up new interdisciplinary approaches to the understanding of memory, involving not only history, ethnology, and anthropology, but also, most importantly, psychology.

\footnotetext{
${ }^{27}$ Words of Ana Nekič, a social worker, who did a research on the psycho-sociological aspects of WW II in the region of Brkini, for her master's degree.
} 


\section{REFERENCES}

ASSMANN, Aleida. 2007. "Europe: A community of memory?". GHI Bulletin, vol. 40:11-25.

ASSMANN, Aleida. 2010. "From Collective Violence to the Common Future: Four Models for Dealing with the Traumatic Past". In Conflict, Memory Transfers and the Reshaping of Europe, eds. Helena Gonçalves da Silva et al. Cambridge: Cambridge Scholars Publishing, 14-22.

BALLINGER, Pamela. 2003. History in Exile. Memory and Identity at the Borders of the Balkans. Princeton: Princeton University Press.

BASKAR, Bojan. 2010. “'That most beautiful part of Italy': Memories of Fascist Empirebuilding in the Adriatic". In Mediterranean Frontiers. Borders, Conflict and Memory in a Transnational World, eds. Dimitar Bechev et al. London - New York: Tauris Academic Studies, 109-128.

“Borci drugič v boj za ime bistriškega vrtca”. 2011. Primorske novice, September 11. http://www.primorske.si/Primorska/Srednja-Primorska/Borci-drugic-v-boj-zaime-bistriskega-vrtca.aspx (accessed August 18, 2017).

BOŽEGLAV, Majda. 1986. Kipar Jože Pohlen. Diploma Thesis. Ljubljana: Filozofska fakulteta.

BRATE, Tadej. 2007. Parenzana: železnica za vse večne čase. Ljubljana: Kmečki glas.

CANDAU, Joël. 2005. Anthropologie de le mémoire. Paris: Armand Colin.

CIPEK, Tihomir. 2009. "Sjećanje na 1945.: čuvanje i brisanje. O snazi obiteljskih narativa”. In Kultura sjećanja: 1945. Povijesni lomovi i svladanje prošlosti, eds. Sulejman Bosto and Tihomir Cipek. Zagreb: Disput, 155-165.

CUNJA, Leander. 2004. Škofije na Morganovi liniji. Škofije: Krajevna skupnost ; Koper: Lipa.

ČAPO ŽMEGAČ, Jasna. 2007. Strangers either Way. The Lives of Croatian Refugees in Their New Home. New York - Oxford: Berghahn Books.

ČAPO ŽMEGAČ, Jasna. 2015. "Prijepori oko naslijeđa prošlosti i memorija u Hrvatskoj: znanstveno-popularna publikacija pod pritiskom ideologija". Studia ethnologica Croatica, vol. 27:105-129.

ČEBRON LIPOVEC, Neža. 2012. “Arhitekturni pomniki izgradnje Kopra po drugi svetovni vojni”. Annales, Series historia et sociologia, vol. 22/1:211-232. https:// www.dlib.si/details/URN:NBN:SI:DOC-VEFT83YG

ČEBRON LIPOVEC, Neža. 2017. "I'm Telling the Story of the Town'. Places in a Contested Space”. In At Home but Foreigners. Population Transfers in $20^{\text {th }}$ Century Istria, eds. Katja Hrobat Virloget et al. Koper: Univerzitetna založba Annales, 189-208.

ČEBRON LIPOVEC, Neža and Katja HROBAT VIRLOGET. (in print). "Dequel and Pohlen: Sculptures of Two Compatriots Telling the Different Views of the Post- 
War Period in Northern Istria". In Heroic Art and Socialist Realism. Memory and Representations of the Socialist Past, ed. Nikolai Vukov. Sofia.

ČEBRON LIPOVEC, Neža, Katja HROBAT VIRLOGET and Andrej PRELOŽNIK. 2017. "Heroes we love... Or not?". In Heroes we love. Ideology, Identity and Socialist Art in New Europe, ed. Simona Vidmar. Maribor: Umetnostna galerija Maribor, 274-288.

ČEPIČ, Zdenko and Dušan NEČAK. 1979. Zgodovina Slovencev. Ljubljana: Cankarjeva založba.

ČOPIČ, Špelca. 2000. Javni spomeniki v slovenskem kiparstvu prve polovice 20. stoletja. Ljubljana: Moderna galerija.

DOTA, Franco. 2010. Zaračeno poraće. Konfliktni i konkurentski narativi o stradanju $i$ iseljevanju Talijana Istre. Zagreb: Srednja Europa.

FIGES, Orlando. 2007. The Whisperers: Private Life in Stalin's Russia. New York: Taylor \& Francis.

FIGES, Orlando. 2009. Šepetalci. Zasebno življenje v Stalinovi Rusiji. Ljubljana: Modrijan.

FIKFAK, Jurij. 2009a. "Cultural and Social Representations on the Border: From Disagreement to Coexistence". Human Affairs, vol. 19/4:350-362. https://doi. org/10.2478/v10023-009-0049-1

FIKFAK, Jurij. 2009b. "Simboli in ritualne prakse spora in sožitja. Nekateri italijanskoslovenski diskurzi”. Studia ethnologica Croatica, vol. 21:355-387. https://hrcak. srce.hr/45126

GHODSEE, Kristen 2014. "Tale of 'Two Totalitarianisms': The Crisis of Capitalism and the Historical Memory of Communism". History of the Present: A Journal of Critical History, vol. 4/2:115-142. https://doi.org/10.5406/historypresent.4.2.0115

GOMBAČ, Jure. 2005. Ezuli ali optanti? Zgodovinski primer v luči sodobne teorije. Ljubljana: Založba ZRC.

HALBWACHS, Maurice. 1992. On collective memory. Chicago: University of Chicago Press.

HALL, Stuart. 2008. "Whose Heritage? Un-settling 'The Heritage', reimagining the postnation". In The Heritage Reader, eds. Graham Fairclough et al. London - New York: Routledge, 219-228.

“Heroj čaka na spomenik". 2009. Primorski dnevnik, August 22. www.primorski.it/stories/ alpejadran/49739_heroj_aka_na_spomenik/\#.WZRSK9R97Gg (accessed August $18,2017)$.

HROBAT VIRLOGET, Katja. 2015a. "The Burden of the Past. Silenced and Divided Memories of the Post-war Istrian Society". In At Home but Foreigners. Population Transfers in $20^{\text {th }}$ Century Istria, eds. Katja Hrobat Virloget et al. Koper: Univerzitetna založba Annales, 159-188. 
HROBAT VIRLOGET, Katja. 2015b. "Breme preteklosti. Spomini na sobivanje in migracije v slovenski Istri po drugi svetovni vojni". Acta Histriae, vol. 23/3:531-554. http://zdjp.si/wp-content/uploads/2015/12/Pages-from-Acta-Histriae-\%C5\%A1t.3-letnik-23-2015_HROBAT-VIRLOGET_LOWRES.pdf (accessed June 13, 2017).

HROBAT VIRLOGET, Katja. 2017. "O molku v etnografiji. Od skrivnosti do travme in nekompatibilnih spominov". Traditiones (in print).

HROBAT VIRLOGET, Katja, Catherine GOUSSEFF and Gustavo CORNI, eds. 2015. At Home but Foreigners. Population Transfers in $20^{\text {th }}$ Century Istria. Koper: Univerzitetna založba Annales.

HROBAT VIRLOGET, Katja, Saša POLJAK ISTENIČ, Neža ČEBRON LIPOVEC and Mateja HABINC. 2016. "Abandoned Spaces, Mute Memories: On Marginalized Inhabitants in the Urban Centres of Slovenia". Glasnik Etnografskog instituta, vol. 64:77-90.

KACIN-WOHINZ, Milica [M. K.-W.]. 1990. "Tomažič (Tomasi), Pino (Josip, Pinko)”. In Primorski slovenski biografski leksikon, vol. 16 (Tič-Velikonja). Gorica: Goriška Mohorjeva družba, 8-9. http://www.sistory.si/cdn/publikacije/1-1000/272/ Primorski_slovenski_biografski_leksikon_16.pdf (accessed August 16, 2017).

KLABJAN, Borut. 2012. "'Partizanska pokrajina': partizanski spomeniki in komemoriranje partizanov na Tržaškem". Acta Histriae, vol. 20/4:669-692. http://www.dlib.si/ details/URN:NBN:SI:doc-JXZYWZKN

MALEC, Tatjana. 2006. “O črnih bratih”. Sunčeve pozitivke, January 6. http://www. pozitivke.net/article.php/OCrnihBratih (accessed August 16, 2017).

NEMEC, Gloria. 2015. "The Hardest Years: Private Stories and Public Acknowledgment in the Recollection of Istrian Italians, Either Exiled or Stayed Behind". In At Home but Foreigners. Population Transfers in $20^{\text {th }}$ Century Istria, eds. Katja Hrobat Virloget et al. Koper: Univerzitetna založba Annales, 145-158.

NORA, Pierre. 1989. "Between Memory and History: Les Lieux de Mémoire". Representations, vol. 26:7-25. https://doi.org/10.2307/2928520

PASSERINI, Luisa. 2008. Ustna zgodovina, spol in utopia. Izbrani spisi. Ljubljana. Studia humanitatis.

PERME, Franc, ŽITNIK Anton and Davorin ŽITNIK, eds. 2000. Slovenija 1941-19481952: tudi mi smo umrli za domovino: zamolčani grobovi in njihove žrtve. Ljubljana - Grosuplje: Društvo za ureditev zamolčanih grobov

PIRJEVEC, Jože. 2000. Trst je naš, boj Slovencev za morje (1848-1954). Ljubljana: Nova revija.

PIRJEVEC, Jože. 2009. Foibe. Una storia d'Italia. Torino: Einaudi.

PLAHUTA, Slavica [Plah.]. 1984. "Maslo Karlo". In Primorski slovenski biografski leksikon, vol. 10 (Martelanc - Omersa). Gorica: Goriška Mohorjeva družba, 385-385. http://www.sistory.si/cdn/publikacije/1-1000/266/Primorski_slovenski_ biografski_leksikon_10.pdf (accessed August 16, 2017). 
PREDMEJC. 2010. "Karlo Maslo PROSLAVA 24. aprila 2010 1. del”. YouTube.com, August 5. https://www.youtube.com/watch?v=XZXmNpimyYo (accessed August $16,2017)$.

PREDMEJC. 2010. "Karlo Maslo PROSLAVA 24. aprila 2010 2. del”. YouTube.com, August 5. https://www.youtube.com/watch?v=rDO_XxSTkzY (accessed August $16,2017)$.

PUPO, Raoul. 2015. "Italian Historiography on the Istrian Exodus. Topics and Perspectives". In At Home but Foreigners. Population Transfers in $20^{\text {th }}$ Century Istria, eds. Katja Hrobat Virloget et al. Koper: Univerzitetna založba Annales, 25-48.

PURGER, Ajda. 2016. "Modernistična kamnita kiparska dediščina na prostem - primeri ohranjanja v treh slovenskih obalnih občinah”. In Povezave, ed. Mateja Golež. Ljubljana: ZAG, 163-180.

RADOŠEVIĆ, Milan. 2011. "Franco Dota, Zaračeno poraće. Konfliktni i konkurentski narativi o strdanju i iseljevanju Talijana Istre. Zagreb, Srednja Europa, 2010, 149 str." Histria, vol. 1:242-246.

RIEGL, Alois (1996 [1903]). "The Modern Cult of Monuments: Its Essence and Its Development. (original title: Der moderne Denkmalkultus: sein Wesen und seine Entstehung)". In Historical and Philosophical Issues in the Conservation of Cultural Heritage, eds. Nicholas Stanley Price et al. Los Angeles: Getty Conservation Institute, 69-83.

ROGOZNICA, Deborah. 2011. Iz kapitalizma v socializem. Gospodarstvo cone B Svobodnega tržaškega ozemlja 1947-1954. Koper: Pokrajinski arhiv Koper.

SILIČ NEMEC, Nelida. 1982. Javni spomeniki na Primorskem: 1945 - 1978. Koper: Lipa ; Trst: Založništvo tržaškega tiska ; Nova Gorica: Goriški muzej.

SMITH, Andrea L. 2006. Colonial memory and postcolonial Europe. Bloomington: Indiana University Press.

TROHA, Nevenka. 1997. "STO - Svobodno tržaško ozemlje”. In Zbornik Primorske - 50 let, ed. Slobodan Valentinčič. Koper: Primorske novice, 56-60.

VERGINELLA, Marta. 2000. “L'esodo istriano nella storiografia slovena”. In Trasferimenti forzati di popolazione nel Novecento europeo, eds. Marina Cattaruzza et al. Napoli: Edizioni scientifiche italiane, 269-277.

VERGINELLA, Marta. 2015. "Writing Historiography on Migrations at the Meeting Point of Nations in the Northern Adriatic". In At Home but Foreigners. Population Transfers in $20^{\text {th }}$ Century Istria, eds. Katja Hrobat Virloget et al. Koper: Univerzitetna založba Annales, 49-70.

VESCHAMBRE, Vincent. 2008. Traces et mémoires urbaines. Enjeux sociaux de la patrimonilasation et de la démolition. Rennes: PUR.

ZNIDARČIČ, Asta and Breda ILICH-KLANČNIK. 2013. "Zorko, Vlasta (1934-)". In Slovenska biografija. Ljubljana: Slovenska akademija znanosti in umetnosti, Znanstvenoraziskovalni center SAZU. http://www.slovenska-biografija.si/oseba/ 
sbi876126/\#slovenski-biografski-leksikon (accessed February 10, 2017). [Original in: Slovenski biografski leksikon: 15. zv. Zdolšek - Žvanut, eds. Jože Munda et al. Ljubljana: Slovenska akademija znanosti in umetnosti Znanstvenoraziskovalni center SAZU, 1991].

ZOMBORY, Máté. 2012. Maps of Rememberance. Space, Belongng and Politics of Memory in Eastern Europe. Budapest: L'Harmattan.

ŽIGON, Zdenka. 2013. "Premrl, Janko (Vojko)". Primorci.si, October 29. http://www. primorci.si/osebe/premrl-janko-(vojko)/853/ (accessed February 10, 2017).

\section{SOURCES}

ZORKO, Vlasta. 2016. Interview with Vlasta Zorko (1934), realized by Andrej Preložnik, 13 May 2016. Record stored by the authors of the article.

Interviews with anonymous persons - transcripts written by Katja Hrobat Virloget.

Katja Hrobat Virloget

Neža Čebron Lipovec

\section{HEROJI KOJE VOLIMO? SPOMENICI NARODNOOSLOBODILAČKOM POKRETU U ISTRI, IZMEĐU SJEĆANJA, BRIGE I KOLEKTIVNE TIŠINE}

Spomenici Narodnooslobodilačkoj borbi u Drugom svjetskom ratu u pograničnom području između Slovenije i Italije, naime u Istri, zrcala su sukobljenih sjećanja na međunarodnoj i regionalnoj razini između dvije zemlje i dvije nacionalnosti koje u toj regiji žive. Kao materijalna mjesta službenog sjećanja, spomenici istodobno odražavaju tenzije u odnosu na individualna sjećanja i upornu kolektivnu šutnju koja traje desetljećima nakon pada službenog sjećanja prošloga jugoslavenskog sustava.

Ključne riječi: spomenici, heroji, Drugi svjetski rat, sjeverna Istra, sukobljena sjećanja, tišina, Slovenci, Talijani

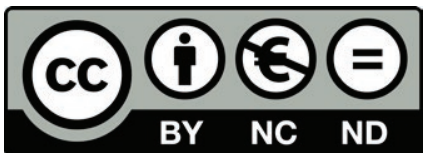

Articles published in this journal are Open Access and can be distributed under the terms and conditions of the Creative Commons license Attribution-NonCommercial-NoDerivatives 4.0 (http://creativecommons.org/licenses/by-nc-nd/4.0/) 